\title{
EXPLORING THE USEFULNESS OF RICH MATHEMATICAL TASKS TO ENHANCE STUDENTS' REFLECTIVE THINKING
}

\author{
Fitriati Fitriati $^{1 *}$, Rita Novita ${ }^{1}$, Rahmah Johar $^{2}$ \\ ${ }^{1}$ STKIP Bina Bangsa Getsempena, Indonesia \\ ${ }^{2}$ Universitas Syiah Kuala, Indonesia \\ *e-mail: fitriati@bbg.ac.id
}

\begin{abstract}
Promoting reflective thinking in daily teaching practice is vital to prepare students to live in a more challenging world. Rich tasks are one of the promising tasks that could be used as pedagogy trend to develop students' reflective thinking. Therefore, the purpose of this study is to describe the usefulness of rich mathematical tasks including how teachers use them in their teaching practice and the improvement of students' reflective thinking following the rich tasks based instruction. This study employed a teaching experiment within a case study design. Participants were 28 grade 7 students of one junior high school in Aceh, Indonesia. The instrument of the study is three valid and reliable rich mathematical tasks administered to the students through student worksheets. The results of the study showed that rich tasks provided students with the opportunity to solve real-world problems by questioning their understanding and thinking reflectively. It was also found that most students in the classroom were able to achieve the low level reflective thinking with a classroom mean score of 60 . This value was fairly enough since reflective thinking is a complicated concept. Subsequently, the results indicated the rich mathematical tasks approach were potential in enhancing students' reflective thinking ability.
\end{abstract}

\section{Keywords: rich tasks, mathematics instruction, reflective thinking}

\section{EXPLORASI KEGUNAAN RICH TASK MATEMATIKA UNTUK MENINGKATKAN KEMAMPUAN BERPIKIR REFLEKTIF SISWA}

\begin{abstract}
Abstrak: Pengembangan kemampuan berpikir reflektif dalam praktik pembelajaran sehari-hari sangat penting dalam mempersiapkan siswa untuk hidup di dunia yang penuh tantangan. Rich tasks merupakan sebuah aktivitas belajar yang dapat digunakan sebagai sebuah tren pedagogi untuk mengembangkan berpikir reflektif siswa. Oleh karena itu, tujuan penelitian ini adalah untuk medeskripsikan kegunaan rich task matematika yang meliputi bagaimana guru mengimplementasikan rich tasks dalam pembelajaran dan peningkatan kemampuan berpikir reflektif siswa setelah mengikuti pembelajaran berbasis rich tasks. Penelitian ini menggunakan ekperimen pembelajaran dalam desain studi kasus. Partisipan adalah 28 siswa kelas 7 di salah satu Sekolah Menengah Pertama di Banda Aceh, Indonesia. Instrumen penelitian yang digunakan adalah tiga rich tasks matematika yang valid dan realibel yang diberikan kepada siswa melalui LKS. Hasil penelitian menunjukkan bahwa rich tasks memberikan siswa kesempatan untuk menyelesaikan masalah dunia nyata dengan mempertanyakan pemahaman serta pemikiran mereka secara refleksi. Studi ini juga menemukan bahwa sebagian besar siswa dalam kelas telah mampu mencapai level rendah dari tingkatan berpikir reflektif dengan rata-rata kelas sebesar 60. Nilai ini dianggap cukup karena berpikir reflektif merupakan konsep yang rumit. Dengan demikian, hasil penelitian ini mengindikasikan bahwa rich tasks matematika memiliki potensi dalam meningkatkan kemampuan berpikir reflektif siswa.
\end{abstract}

Kata Kunci: rich tasks, pembelajaran matematika, berpikir reflektif

\section{INTRODUCTION}

Development of reflective thinking among students become the center of current reform in mathematics education. It is an essential skill to contemporary life, especially to enter the workforce and navigate the complex world
(Kramarski, Mevarech, \& Arami, 2002), which required workers to rethink and solve realworld problems regularly. Many studies have stressed the important of promoting reflective thinking in daily teaching practice (Dervent, 2015; Kramarski et al., 2002; Demirel, Derman, 
\& Karagedik, 2015) because it provides students with an opportunity to step back and think about how they actually solve problems, as well as how a particular set of problem-solving strategies might be appropriated for achieving their goal (Porntawekul \& Raksasataya, 2012). Moreover, reflective thinking helps learners develop higherorder thinking skills by prompting learners to relate new knowledge to prior understanding, think in both abstract and conceptual terms, apply specific strategies in novel tasks, and understand their thinking and learning strategies (Dewey, 1910; Kadivar, Tanha, Sh, \& Farzad, 1993). These show that the benefit of reflective thinking is lifelong. Therefore, current mathematics curriculum should be designed and arranged to provide the opportunity to student develop a high level of mathematical competences as documented in TIMSS and PISA problemsolving skills such as modelling, and reflective thinking.

Indonesian Government initiates the new curriculum in year 2013, called Curriculum 2013 which developed based on the comprehensive evaluations of TIMSS and PISA results (Ministry of Education \& Culture, 2013). Both studies' results show that Indonesian students performance in mathematics has been consistently ranked in a low position. Further study of PISA results found that their performance on level five and six questions of mathematics test which measured their higher order thinking skills such as reflective thinking and problemsolving ability is weak (Stacey, 2011). This indicates that the current Indonesia mathematics curriculum teaches something different than what is needed. Thus, the new 2013 curriculum and assessment focus on a range of $21^{\text {st }}$ century skills, with the aim of mathematics education is to develop students' skills such as reasoning, communication, problem solving that required higher order thinking including reflective thinking preparing them to live in challenging world (Ministry of Education \& Culture, 2013).

While there is widespread agreement on the importance of incorporating reflective thinking into mathematics classrooms, there is limited specific advice on how this can best happen. The new curriculum requires the teachers to employ constructivist teaching and learning strategies to develop HOTS including reflective thinking, such as project-based learning, problem-based learning, contextual learning and collaborative-based learning (Ministry of Education \& Culture, 2013). However, the teaching practices implemented by teachers merely focused on traditional teaching methods (Tanujaya, Prahmana, \& Mumu, 2017). Nuriadin, Kusumah, Sabandar, \& Dahlan (2015) stated that mathematics instruction delivered by teachers not get used to develop students' thinking ability. They used to explain mathematical concept through formulations which then affected low of students' mathematical reflective thinking performance. In addition, most of the previous studies conducted about the reflective thinking skills focused more on the factor analysis such as Kadivar et al. (1993) studied the effect of reflective thinking on academic achievement; Phan (2006) also examined student approach and reflective thinking with a latent variable approach; Demirel et al. (2015) studied the relationship between reflective thinking skill toward problem-solving and attitude toward mathematics, and how teaching strategy relate to reflective thinking (Aizikovitsh-udi \& Cheng, 2015). Only a few studies focus directly on how to teach students to develop reflective thinking. This includes study of using Mathlet conducted by Avetisyan \& Hayrapetyan (2017); employing knowledge sharing learning (Nuriadin et al., 2015), feedback dialog (van der Schaaf, Baartman, Prins, Oosterbaan, \& Schaap, 2013), problem based learning (Kurniawati, Kusumah, Sumarmo, \& Sabandar, 2014). However, most of these studies conducted among university students and teachers. This indicates that further research concerning teaching reflective thinking among secondary school students is still needed.

One of the promising mathematical tasks that could be used to stimulate students' mathematical reflective thinking ability is a rich task. A rich task was defined by Moulds (2002) as a task that can engage students in the learning process, make contents meaningful and foster connections among ideas and disciplines. Ferguson (2009) stated that it is the tasks in which the whole class can engage and can easily be adjusted to students' ability level. The rich task could provide student learning opportunity to solve real-world problems that required higher order thinking skills including reflective thinking and reasoning (Henningsen \& Stein, 1997). These indicate that rich tasks are one avenue for 
teaching students to solve real-world problems that challenge them to engage in the learning process actively and to make connections between concepts and ideas. Therefore, teachers are challenged to create and apply rich tasks in daily teaching practices.

Rich tasks have a range of characteristics that make it an effective component in teaching mathematics. These include trans-disciplines, authenticity in their relationship to real-world applications and contexts, offer different levels of challenges, purposeful connections to the world beyond classrooms, encourage critical thinking and offer various opportunities to meet the different need of the learners and resources intensity (Aubusson, Burke, Schuck, Kearney, \& Frischknecht, 2014; Ferguson, 2009; Goos, Geiger, \& Dole,, 2013; Henningsen \& Stein, 1997; Moulds, 2002; Piggott, 2011). This potential of rich tasks has been indicated by a body of literature (Goos et al., 2013; Moulds, 2002). Consequently, many education standards and curriculum guidelines around the world have encouraged teaching practices that involve rich tasks elements (Queensland Department of Education, 2001) and mandate to create more complex tasks to prepare students to live in the challenging world. In response to this, a bank of rich tasks now exists across grade levels, along with scoring rubrics and moderating processes by which the quality of the tasks, the student works, and the scoring can be evaluated (such as NRICH, ATM, and MCTP).

Some studies about rich tasks have been carried out such as Moulds (2002); Slavit \& Nelson (2010); Goos et al. (2013) which show that the role of rich tasks in developing student learning. A body of literature (Aubusson et al., 2014; Ferguson, 2009; Goos et al., 2013; Henningsen \& Stein, 1997; Moulds, 2002; Nelson, 2010; Piggott, 2011) have reported the potential of rich tasks such as challenges students to solve real-world problems which have a connection to the world beyond classrooms, encourages them to think reflectively and offer various opportunities to meet the different need of the learners. Regarding these potentials of a rich task, it is suggested that a rich task could be used to address some of the problems in mathematics education in Indonesia, more specifically in improving students reflective thinking ability in mathematics which still weak as previously reported by Stacey (2011). Moreover, study about implementing rich tasks in mathematics classroom in Indonesia is still limited, even the rich tasks approach is not common in Indonesia. Consequently, this study came to bridge the gap as an addition to knowledge in this approach.

The purpose of this study is to describe the usefulness of rich mathematical tasks including how teachers use them in their teaching practice and the improvement of students' reflective thinking following the rich tasks based instruction.

\section{METHODS}

The method of this study involved a teaching experiment within a case study design (Yin, 2003). One of the researchers (FT) assumed the role of the teachers and engaged in reflective practice while the other researcher provided feedback as a non-participant observer (RN). Instruction materials such as lesson plans, student worksheets, rubrics, and scoring guidelines were designed and provided by the researchers. Students worked in groups and experienced 5 hours weekly of mathematics classroom using rich tasks over two meetings. The instruction procedure utilized in this study follows the problem-based instruction method as reported by Saputra, Joyoatmojo, Wardani, \& Sangka (2019) by including three rich tasks. This method was used as it is potential to improve reflective thinking (Narmaditya, Wulandari, \& Sakarji, 2018). Following this method, the instruction process consists of five phases: (1) providing the problems to students where the students are oriented to the rich tasks; (2) students identified problems within the tasks; (3) students sought information from various sources; (4) students choose the right solution to solve tasks; and (5) Teacher evaluated the students' works.

This study was conducted in Banda Aceh, Aceh Province, Indonesia. The participants were 28 (11 boys and 17 girls) Year 7 students of one the junior high school in Banda Aceh. This class was selected among eight classrooms in the school based on their interest and strength in mathematics especially mastering some algebraic and procedural knowledge as reported by their teacher. This technique was established using convenient sampling. As this study was the first initial program to introduce rich tasks to the students, the participants of this study never 
solved mathematics problems like rich tasks before.

Based on an extensive review of rich task bank items from Educational Designer (Burkhardt, 2009) and NRICH (2014), researchers select three rich mathematical tasks that suit year 7 mathematics curriculum in Indonesia. These selected tasks were modified by the researchers to adopt the local contexts and were then assessed using rich task framework developed by Goos et al. (2013) to ensure the richness of the tasks. Tessmer (1993) evaluation method was also employed to assure the validity and reliability of the modified tasks in measuring and reflective thinking (RT) ability of the students. A summary of the given rich task is provided in Table 1.

Cronbach's alpha coefficient for internal consistency was obtained based on the students' responses to each rich task item making up the instrument to ensure the test reliability. The total value of the alpha coefficient for the test was satisfactory (.71) (Santos, 1999). The valid and reliable tasks were then arranged within student worksheet (Fitriati \& Novita, 2018) administered to seven groups of student in a mathematics classroom using a problem-based approach (Saputra et al., 2019). In addition, the researchers developed a classroom observation checklist based on rich tasks trajectory (Goos et al., 2013) to gather data related to how students are learning mathematics with rich tasks.

The data analysis used in this study was a qualitative approach consisting of transcribing, analyzing thematically, and organizing into categories (Corbin \& Strauss, 2008). Data such as classroom observation on student and teacher activities and students' responses were used simultaneously to portrait how mathematics instruction with rich task use to develop students' reflective thinking and to present students' reflective thinking performance. Reflective thinking ability of the students was measured based on the students' responses on a rich task which was formatted based on open constructed-response items. Score ranged from 0 (no response or incorrect response) to 100 (full correct response).

A full correct answer for each task corresponds to reflective thinking indicators consisted of (a) identifying what is known and unknown about the problems and understanding the given information, information discovered while interacting with the problem situation (R1); (b) selecting right strategy to solve given problem and planning consisted of goal setting, clarifying the subgoal or overall goal, devising a plan or strategy to reach goal including the steps to be undertaken (R2); (c) presenting selected strategy and devised plan (R3); (d) carrying out the plan (R4); and (e) critically evaluating assumption and alternative solutions and looking for additional information or clarification (R5). These indicators are then assigned to the four levels of reflective thinking, namely the habitual action, understanding, reflection, and critical reflection (Phan, 2006). The reflective thinking scores were also classified into five categories of M10 (mark scheme). The score ranged from $0-49$ is classified as fail, $50-64$ is pass, $65-74$ is credit, 75-84 is distinction and $85-100$ is high distinction.

\section{FINDINGS AND DISCUSSION}

The results reported here is part of our ongoing longterm rich tasks project which focus on the exploration of rich tasks potentials, especially on how teacher used them in mathematics classroom to enhance students' reflective thinking and the improvement of the students' ability following the rich tasks based instruction. These preliminary results will

Table 1. Overview of a Rich Task

\begin{tabular}{cl}
\hline Task & \multicolumn{1}{c}{ Task Description } \\
\hline 1 & $\begin{array}{l}\text { Security Camera: The topic of this task is the rotation, it is modified with the local context } \\
\text { (well-known book and stationery store in Banda Aceh) and consists of } 3 \text { task items: } 1 \mathrm{a}, 1 \mathrm{~b},\end{array}$ \\
& $\begin{array}{l}\text { and 1c. } \\
2\end{array}$ \\
& $\begin{array}{l}\text { Traffic Jam: The topic of this task is statistics, it is modified with local context (traffic caused } \\
\text { by common landslide happening in Aceh) and consist of } 3 \text { task items: } 2 \mathrm{a}, 2 \mathrm{~b}, \text { and } 2 \mathrm{c} .\end{array}$ \\
3 & $\begin{array}{l}\text { Table Tennis Tournament: The topic of the task is a chance. It is modified with school context } \\
\text { (extracurricular activities) and consists of } 3 \text { task items: } 3 \mathrm{a}, 3 \mathrm{~b}, \text { and 3c. }\end{array}$ \\
\hline
\end{tabular}

Exploring the Usefulness of Rich Mathematical Tasks to Enhance ... 
contribute to an understanding of the breadth and the nature of mathematics instruction using rich tasks and students experience in solving rich tasks.

\section{Findings}

Mathematics instruction was delivered through problem based learning method with rich tasks. Through this method, students were trained to solve mathematical problems, in this case are rich tasks, using various strategies and existing problem solving step (Retnowati, Fathoni, \& Chen, 2018). Teacher's and students' activities with rich tasks observed in this study are summarized in Table 2. For example, in guiding students to solve the tasks 2 . The topic for task 2 is "statistics formulated in the traffic jam problem" which can be seen in the Figure 1.

To do the rich tasks 2, teacher prepare materials such as students worksheet and rubric for student response. In this class session, students worked in a group of 4 . This is conducted to enable the teacher to observe their activities. In the beginning, the teacher explained what lesson is about, what teacher expectation had from the lesson (such as solving rich task to explore their

Table 2. Teacher and Student Activities with the Rich Task

\begin{tabular}{|c|c|c|c|}
\hline No. & $\begin{array}{c}\text { Rich Task } \\
\text { Characteristics }\end{array}$ & Teacher Activities & Student Activities \\
\hline 1. & $\begin{array}{l}\text { Provided students } \\
\text { the opportunity to } \\
\text { solve real-world } \\
\text { problems }\end{array}$ & $\begin{array}{l}\text { Teacher exposed students to rich } \\
\text { tasks }\end{array}$ & $\begin{array}{l}\text { Students work collaboratively in } \\
\text { a group to solve given rich tasks } \\
\text { which are real-world problems }\end{array}$ \\
\hline 2. & $\begin{array}{l}\text { Challenge } \\
\text { students to } \\
\text { actively engage } \\
\text { in the learning } \\
\text { process }\end{array}$ & $\begin{array}{l}\text { Teacher guide student by asked } \\
\text { several questions to provoke them } \\
\text { and generate rich mathematical } \\
\text { activity }\end{array}$ & $\begin{array}{l}\text { - Students posed more questions } \\
\text { related to the tasks clarifying } \\
\text { whether their understandings } \\
\text { about the task were correct or not } \\
\text { - Intensive discussion and } \\
\text { communication among students } \\
\text { and teachers during the instruction } \\
\text { - Students had to collect data by } \\
\text { measuring the length of various } \\
\text { types of cars to calculate some car } \\
\text { trapped in the accident }\end{array}$ \\
\hline
\end{tabular}

3. Make connections Teacher posed students with In solving rich tasks (2), the student between concepts several questions related to and ideas problem-solving such as: (1) What mathematics skills or knowledge could be used to determine a solution? (2) What representations can be used to get a sense of what this is about?

4. Developing a complex reasoning process of problemsolving Teacher posed students with several questions related to problem-solving such as: (1) What is the objective required? (2) How reasonable is the solution?

5. Promote Reflective Thinking The teacher asked students to think reflectively by questioning them as follow: (1) how do you think you are correct? And (2) have you found all the possibilities? should know the concept of mean and unit of measurement

Students assume the variation of the length of cars which were stuck in the traffic jam then develop their reasoning

- Students evaluate their answer whether correct or not by providing the reasons

- Student try to find all possibilities (several methods to solve the tasks) 


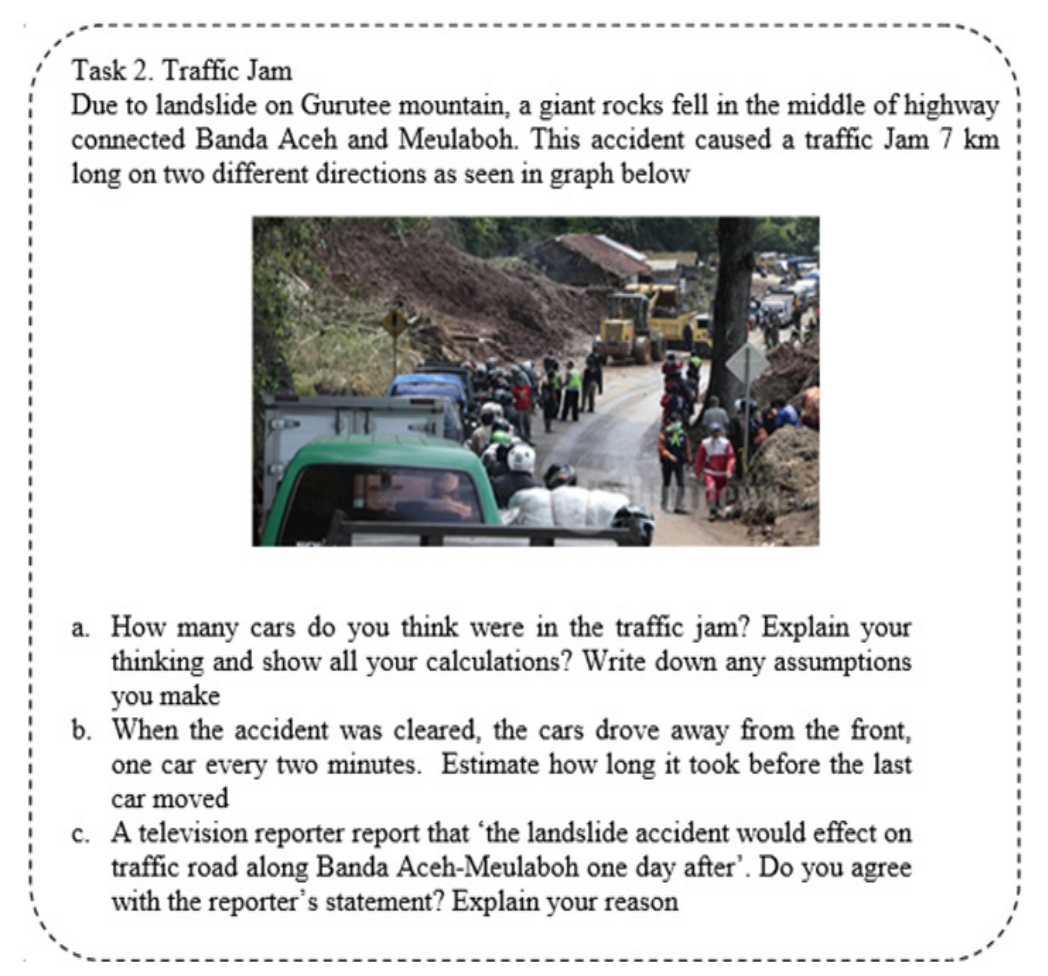

Figure 1. Task 2: Traffic Jam Task

mathematics and reflective thinking ability), and what activities students would do. This provides an example of how these types of tasks may be used to structure student learning. Based on the observation done by researchers during the instruction process, it shows that the rich tasks challenge students. For instance, in completing task 2: traffic jams, students had to collect data by measuring the length of various types of cars to calculate some car trapped in the accident. They are required to assume about the length of each type of car and calculate the average length of the car. These results then were used to calculate the length of time to clear the traffic. To be able to do this, students should use one or two mathematics procedure then monitor and reflect on the process whether it right or not. These activities indicate that the task can invite students to make decisions about how to tackle the activity and what mathematics to use. Also, students are involved in speculating, connecting, testing, explaining, reflecting and interpreting.

The study also reveals that some students found the task was difficult and therefore they asked for teachers' help. In response to this issue, teacher generated rich mathematical activity where the teacher re-questioned the students to provoke learning as was suggested by McDonald \& Watson (2010). Questions can be about context, problem-solving, mathematical connection (mathematics within the tasks and mathematics beyond the task), and reflective thinking. Several questions posed by teachers to guide the students in completing tasks can be seen in Table 2. These questions proposed since the researchers anticipated that the students do not regularly work on rich tasks. They need some more specific starting points, but this does not mean they also need a structured sequence of steps to go through. Questioning was done during rich task implementation as suggested by Johar, Patahuddin, \& Widjaja (2017) who argued that teachers' questioning plays an important role in promoting classroom interaction and scaffold student thinking during the teaching process. Throughout the learning process involving rich tasks, classroom learning experiences were designed to enable students to complete the tasks successfully. These included teaching activities to develop students' mathematics reflective thinking ability. The results of data analysis for classroom score of students' reflective thinking ability is provided in Figure 2.

The highest mean score is pointed to R1 (63.43) then followed by R2 (57.71). It means that most students in the classroom can identify and understand problems and to select and plan strategies. As these two indicators 


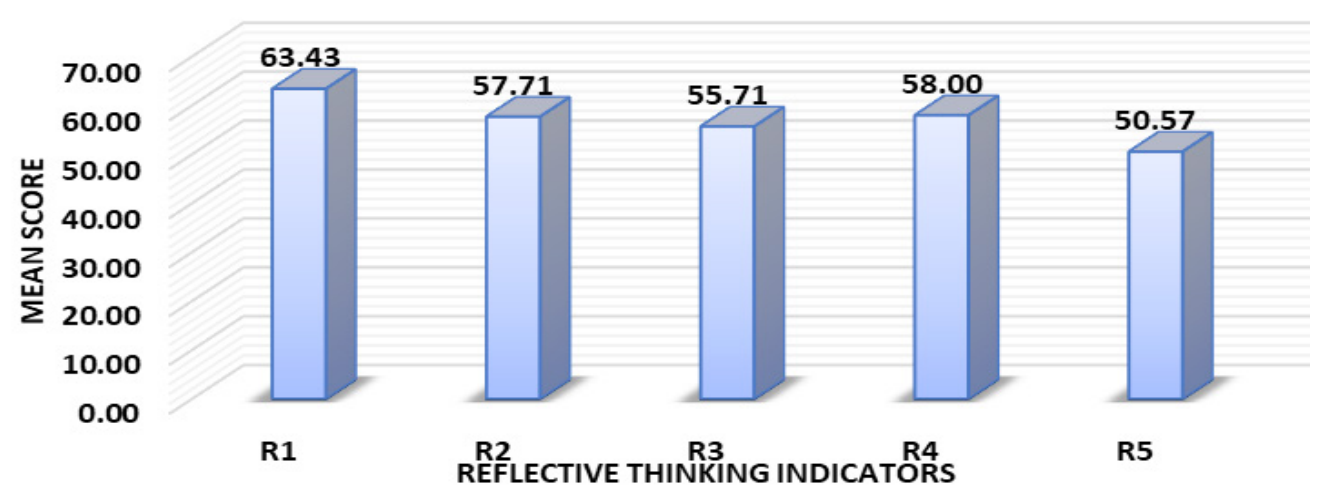

( $\mathrm{R} 1=$ identifying and understanding problem; $\mathrm{R} 2=$ selecting and planning strategies; $\mathrm{R} 3=$ presenting strategies; R4= exploring and executing; $\mathrm{R} 5=$ monitoring and reflecting).

\section{Figure 2. Classroom Mean Score of Reflective Thinking for Each Indicator}

are associated with the low level of reflective thinking, it indicates that most students only achieved the habitual action and understanding level of reflective thinking. However, the lowest score belongs to R5 (50.57) which suggests that this is the most challenging component of reflective thinking to be achieved by students. This condition is true since R5 is associated to the highest level of reflective thinking skill, that is critical reflection level. Even though, these findings show that most students in the classroom were only able to achieve the low level of reflective thinking, further exploration of students' response on given rich tasks found that the average score of reflective thinking for each group of student is fairly enough with four groups of students had high mean scores. The score of reflective thinking for each group is shown in Table 3.

The Table 3 exhibits that the mean score of reflective thinking obtained by seven groups of students who were exposed to rich tasks based instruction is 60 which fall within the 'credit' category. It also provides information about students who had good reflective thinking ability. Group 1, 2, 3 and 4 had a higher mean score (more 70) than group 5, 6, and 7 (below 50) which means that those fourth higher achieved groups had better reflective thinking skill than other three groups.

In addition, analysis of student responses (see Figure 3) indicates that the scaffolding done by the teachers during the instruction process has helped students to always retrieval decisions based on evidence, facts, and knowledge.

Further analysis of student response, especially lower achiever group (see Figure 4 and Figure 5), it is found that these two groups of students even failed to provide their correct assumptions about the average length of cars (R1) which then lead to incorrect way to select and plan strategies (R2) and presenting strategies (R3). When students failed to present the correct calculation of the average length of the car trapped in traffic congestion (item 2a), it will affect the correct response of others items

Table 3. Mean Score of Reflective Thinking for Each Group

\begin{tabular}{|c|c|c|c|c|c|c|c|c|c|c|c|c|}
\hline \multirow{2}{*}{$\begin{array}{l}\text { Group of } \\
\text { Student }\end{array}$} & \multicolumn{9}{|c|}{ Task Item } & \multirow{2}{*}{ Sum } & \multirow{2}{*}{ Mean } & \multirow{2}{*}{ Category } \\
\hline & $1 \mathrm{a}$ & $1 \mathrm{~b}$ & $1 \mathrm{c}$ & $2 a$ & $2 \mathbf{b}$ & $2 c$ & $\mathbf{3 a}$ & $3 \mathbf{b}$ & $3 c$ & & & \\
\hline Group 1 & 100 & 80 & 100 & 60 & 60 & 10 & 90 & 90 & 90 & 680 & 75.56 & Distinction \\
\hline Group 2 & 100 & 80 & 100 & 60 & 60 & 10 & 90 & 90 & 90 & 680 & 75.56 & Distinction \\
\hline Group 3 & 100 & 100 & 100 & 92 & 75 & 90 & 28 & 20 & 20 & 625 & 69.44 & Credit \\
\hline Group 4 & 90 & 100 & 90 & 60 & 60 & 10 & 90 & 90 & 90 & 680 & 75.56 & Distinction \\
\hline Group 5 & 100 & 20 & 80 & 20 & 20 & 10 & 25 & 20 & 20 & 315 & 35.00 & Fail \\
\hline Group 6 & 100 & 80 & 100 & 20 & 20 & 10 & 20 & 20 & 10 & 380 & 35.56 & Fail \\
\hline Group 7 & 100 & 60 & 50 & 72 & 100 & 60 & 18 & 10 & 10 & 480 & 53.33 & Credit \\
\hline \multicolumn{11}{|c|}{ Class Average } & 60.00 & Credit \\
\hline
\end{tabular}


(item $2 b$ and $2 c$ ). This fact can be found from both students' responses, for instance, group 6 directly assumed the number of cars trapped without providing their reason from where that came out. On the other hand, group 5 wrote directly mean of car's length is equal to 7 meters also without explaining their reasons.

Those students' response show that some students in the classroom had low reasoning skill. They also were unable to think reflectively to evaluate their answer whether they use correct way to solve tasks and arrive at correct solution. This is an indication that students need to be trained continuously to develop the skills. Mathematics instruction conducted by teacher should emphasis on students experience solving more rich tasks which then could habituate them to develop reasoning and reflective thinking skills.

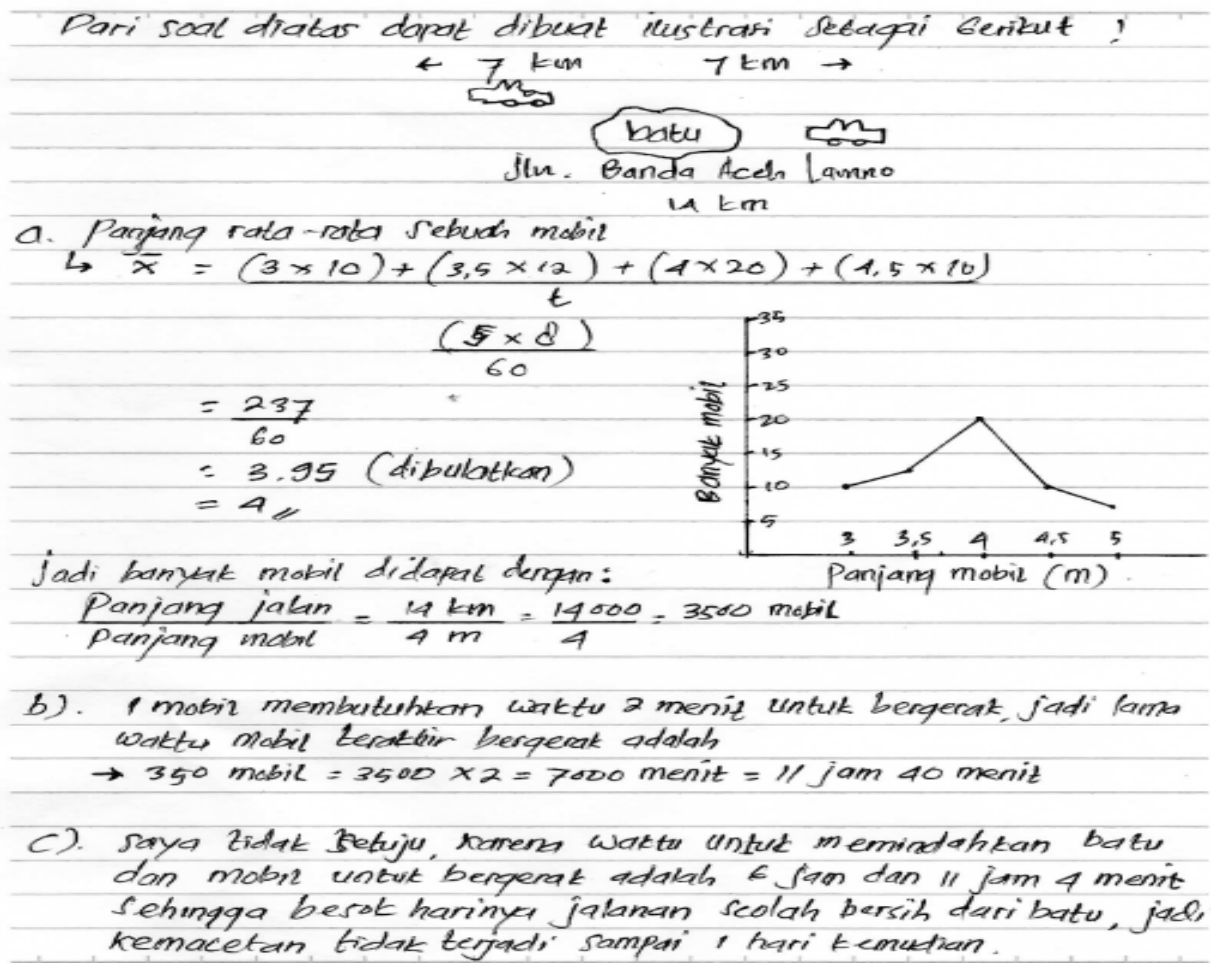

Figure 3. Higher Achiever Group's Response to Task 2

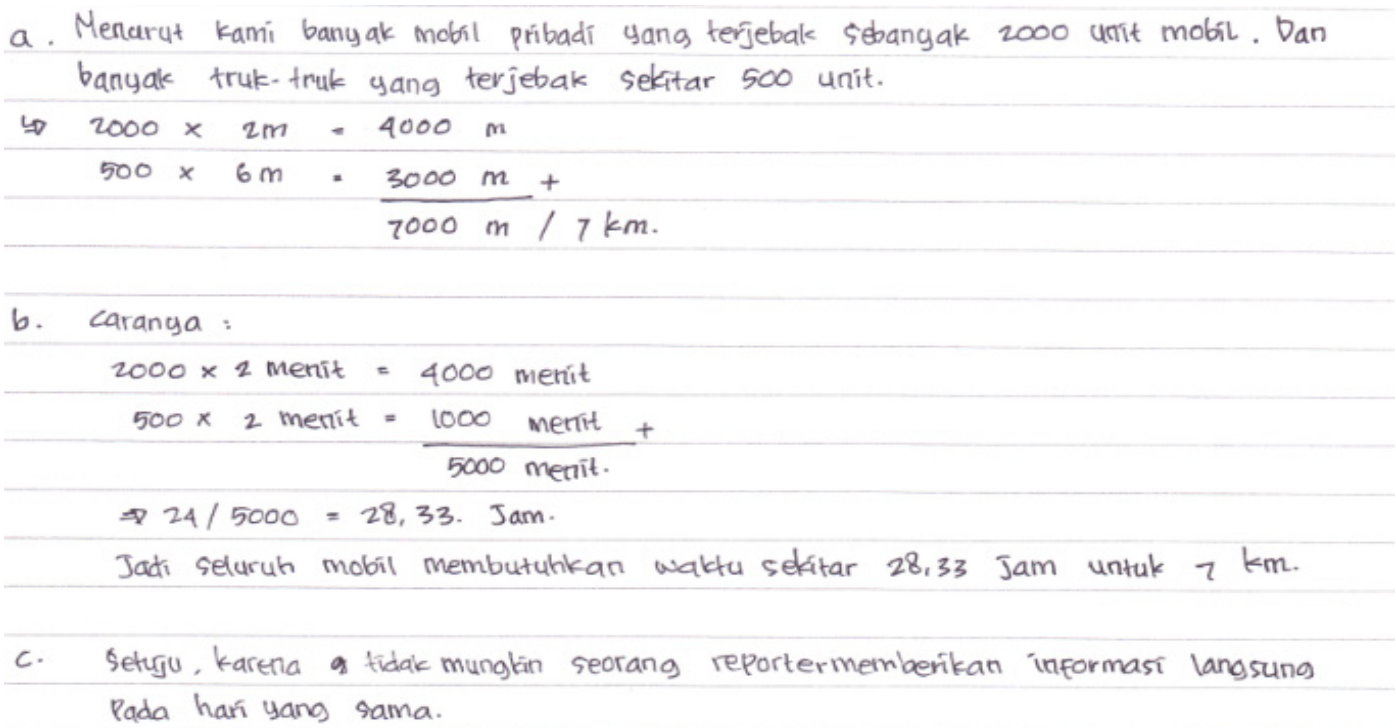

Figure 4. Lower Achiever Group's Response to Task 2 (Group 6) 


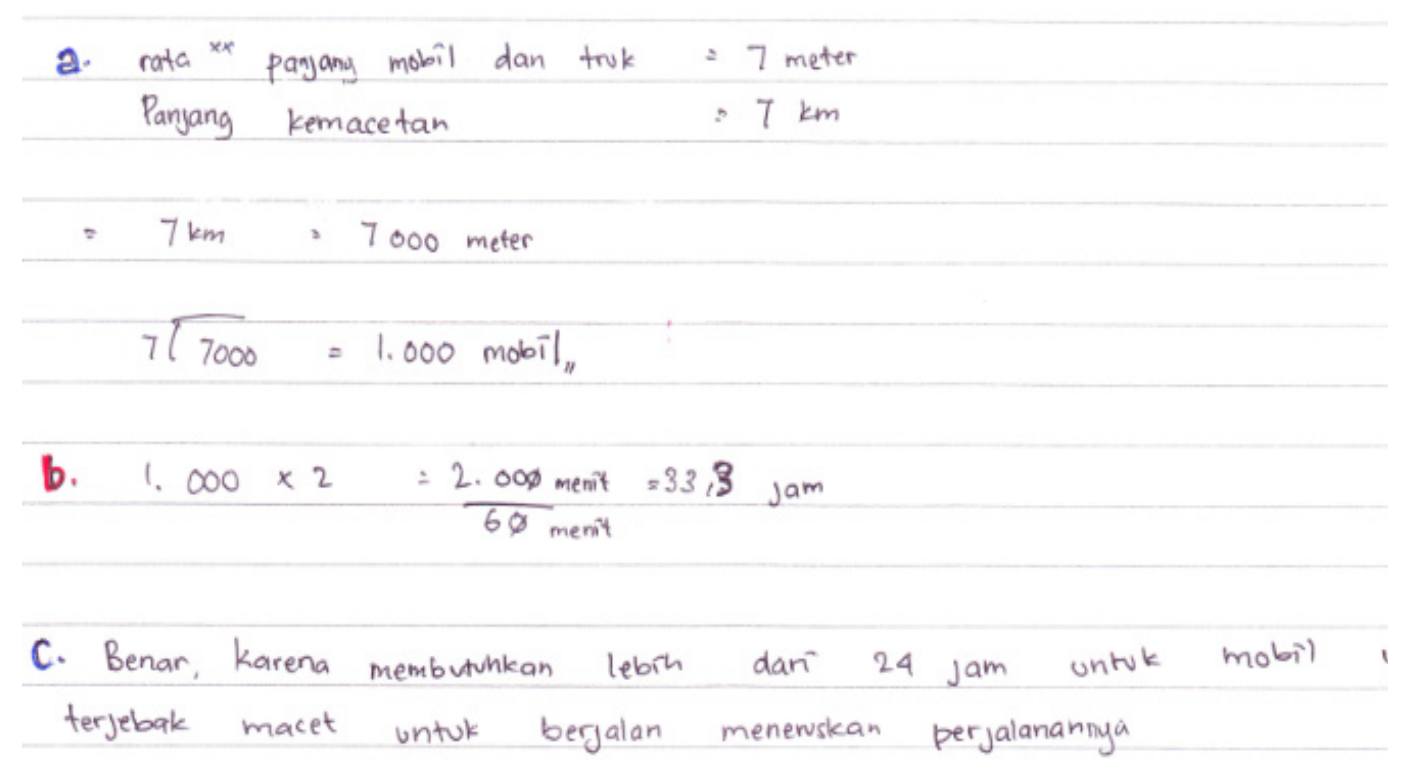

Figure 5. Lower Achiever Group's Response to Task 2 (Group 5)

\section{Discussion}

The potentials of rich tasks in promoting student reflective thinking can be seen from the teacher's effort in facilitating student learning through rich tasks based activity. In preparing students to engage in the traffic jam task (task 2), for instance, teacher made use of five keys learning experiences following the problembased instruction method. In this process, the students developed the necessary knowledge and complex reasoning process to allow them to complete the task successfully, for example, in the first learning activities students were asked to consider the variation of the length of cars which were stuck in the traffic jam. It provided the opportunity for the students in the class to collect data on cars' length. The second learning activities allowed the process of connection where the students correctly used the statistical procedure to calculate the average length of the car and the time needed to clear the traffic. In each of these learning experiences, the students were given opportunities to actively explore and develop important knowledge and processes that would be required to complete the rich task. These learning experiences led to culminating the rich task; students actively gained, refined, extended and applied their understanding in the meaningful context as opposed to learning isolated facts and skills (Piggot, 2011; Margolinas, 2013).

Rich tasks two also required students to think critically by evaluating whether their answer correct or not then provide the reasons. It is believed that this process might promote understanding and meaningful learning. For instance, in solving tasks 2 , students developed an understanding of data collection, estimation to accurately calculated the cars trapped in the traffic, and data evaluation in the real situation instead of doing routine algebra or statistics calculation. These activities indicate that mathematics instruction using rich tasks in daily mathematics classroom could facilitate students to develop their reflective thinking. This finding supports the former studies (Ferguson, 2009; Goos et al., 2013).

Data analysis also exhibits that the tasks engaged students from the beginning of the lesson and allow further challenges. This finding was also corresponded with students' activities where the students posed more questions related to the tasks clarifying whether their understandings about the task were correct or not. The students' engagement also can be seen from intensive discussion and communication among students and teachers during the instruction. These findings indicate that rich tasks is potential as a pedagogical approach to fully engaged students in the learning process which is also mandated by government through the new curriculum 2013 (Ministry of Education \& Culture, 2013).

Regarding reflective thinking improvement, the students' mean score was fairly enough, 60. Even though, this achievement was quite low, it is reasonable enough since 
reflective thinking is a complicated concept (Weshah, 1997). The important thing is that the students getting used to divergent thinking by proposing an alternative solution, although not accurate in solving. This finding is still corresponded with Stacey (2011) who reported that most of Indonesia students perform poorly at reflective thinking ability. This suggests that rich task-based instruction in daily mathematics classroom should be applied routinely so that students get used to solving the contextual problem as the result their reflective thinking might be improved in the future.

This low score also an indication that the students were unable to think critically about the correctness of their answer and their reasoning skills remain weak. The researchers presume that the students not used to validate their answer with reasonable reason in daily mathematics learning. This is because their everyday mathematics experiences mostly based on traditional approach (Tanujaya et al., 2017) which do not contribute to the development of reflective thinking (Weshah, 1997; Nuriadin et al., 2015). Low reflective thinking score among students also could be affected by their lack of conceptual understanding. These finding is inlined with previous studies conducted by Hadi, Retnawati, Munadi, Apino, \& Wulandari (2018) and Alhassora, Abu, \& Abdullah (2017) who found that one of student's problems in solving HOTS items is the lack of conceptual understanding. Therefore, teachers and students need to be trained in leadership skills for successful implementation of rich tasks in the daily mathematics classroom, so that students' reflective thinking can improve in the future.

\section{CONCLUSION}

This study has highlighted rich tasks as one of the avenues for teaching mathematics in meaningful contexts. Overall, the findings indicate that rich tasks based instruction can be used by teachers to enhance students reflective thinking. Therefore, the conclusion of the study has highlighted a few points that should be considered for future instruction. First, using rich tasks a pedagogical approach provides students the opportunity to solve real-world problems and challenge students to engage in the learning process actively, to make connections between concepts and ideas and to allow them to question their understanding and thinking. Second, mathematics instruction involving rich tasks enable students to move beyond the learning of isolated skills and facts to make rich and meaningful connections and develop the complex reasoning process of problem-solving. Finally, by solving rich tasks, the students build their reflective thinking. Although the average score obtained by students is 60 , it trained students to think reflectively and get them used to retrieve decisions based on evidence, facts and knowledge correctly. This helps students to develop such skill during their study.

Rich tasks based instruction has yielded findings of pedagogical importance. The tasks that teachers choose to use in mathematics classroom have a significant impact on the kind of thinking students achieved, their level of engagement and their ability to build conceptual understanding of the mathematical ideas. Mathematics teachers are urged to implement challenging conceptual tasks such as rich tasks to assist students in developing their higher order thinking skills such as problem-solving and reflective thinking.

Finally, some recommendations for further research are proposed. This study was descriptive and lack of a control group, thus limiting the generalization of the results. An experimental study with control group pre-test and posttest is needed to examine the effectiveness of rich tasks in developing reflective thinking among secondary school students. In addition, this study suggests that teachers need a training program on effective practice of rich tasks to be gradually integrated across school curricula and grade level to develop reflective thinking for students.

\section{ACKNOWLEDGMENT}

We gratefully express our gratitude to The Ministry of Research, Technology and Higher Education of Indonesia, STKIP Bina Bangsa Getsempena and Universitas Syiah Kuala, which are kindly funding and supporting the research reported in this paper.

\section{REFERENCES}

Aizikovitsh-udi, E., \& Cheng, D. (2015). Developing critical thinking skills from dispositions to abilities: Mathematics education from early childhood to high. Creative Education, 6(March), 455-462. 
doi:10.4236/ce.2015.64045.

Alhassora, N. S. A., Abu, M. S., \& Abdullah, A. H. (2017). Inculcating higher-order thinking skill in mathematics: Why is it so hard? Man in India, 97(13), 51-62. http:// eprints.utm.my/id/eprint/76878/.

Aubusson, P., Burke, P., Schuck, S., Kearney, M., \& Frischknecht, B. (2014). Teachers choosing rich tasks: The moderating impact of technology on student learning, enjoyment, and preparation. Educational Researcher, 43(5), 219-229. doi:10.3102/0013189X14537115.

Avetisyan, N., \& Hayrapetyan, L. R. (2017). Mathlet as a new approach for improving critical and creative thinking skills in mathematics. International Journal of Education Research, 12(1), 34-44.

Burkhardt, H. (2009). On strategic design. Educational Designer, 1(3), 1-22. https://www.educationaldesigner.org/ ed/volume1/issue3/article9/pdf/ed_1_3_ burkhardt_09.pdf.

Corbin, J. M., \& Strauss, A. L. (2008). Basics of qualitative research: Techniques and procedures for developing grounded theory. Los Angeles, CA: Sage Publications, Inc.

Demirel, M., Derman, I., \& Karagedik, E. (2015). A study on the relationship between reflective thinking skills towards problem solving and attitudes towards mathematics. Procedia-Social and Behavioral Sciences, 197(February), 2086-2096. doi:10.1016/j. sbspro.2015.07.326.

Dervent, F. (2015). The effect of reflective thinking on the teaching practices of preservice physical education teachers. Issues in Educational Research, 25(3), 260-275. http://www.iier.org.au/iier25/dervent.pdf.

Dewey, J. (1910). How we think. Boston, MA: D. C. Heath \& Co., Publisher.

Ferguson, S. (2009). Same tasks, different paths: Catering for students' diversity in mathematics classroom. Australian
Primary Mathematics Classroom, 14(2), 32-36.

Fitriati, F., \& Novita, R. (2018). Designing student worksheet for rich mathematical tasks. Journal of Physics: Conference Series, 1088(012029), 1-7. doi:10.1088/17426596/1088/1/012029.

Foster, C. (2017). Developing mathematical fluency: Comparing exercises and rich task. Educational Studies in Mathematics, 97(2), 121-141. doi:10.1007/s10649-0179788-x.

Glover, A. (2016). Exploring misconception with rich tasks. Ohio Journal of School Mathematics, 73(Spring), 43-49. https:// kb.osu.edu/handle/1811/80137.

Goos, M., Geiger, V., \& Dole, S. (2013). Designing rich numeracy tasks. In $\mathrm{C}$. Margolinas (Ed.). Proceedings of ICMI study 22: Task design in mathematics education. Oxford, UK: International Commission on Mathematical Instruction (ICMI), pp. 591-599.

Hadi, S., Retnawati, H., Munadi, S., Apino, E., \& Wulandari, N. F. (2018). The difficulty of high school students in solving higher-order thinking skills problems. Problems of Education in the 21st Century, 76(4), 520-532. http://oaji.net/ articles/2017/457-1533495738.pdf.

Henningsen, M., \& Stein, M. K. (1997). Mathematical tasks and student cognition: classroom-based factors that support and inhibit high-level mathematical thinking and reasoning. Journal for Research in Mathematics Education, 28(5), 524-549. doi:10.2307/749690.

Johar, R., Patahuddin, S. M., \& Widjaja, W. (2017). Linking pre-service teachers' questioning and students' strategies in solving contextual problems: A case study in Indonesia and the Netherlands. The Mathematics Enthusiast, 14(1), 101-128. $\mathrm{h}=\mathrm{p}: / /$ scholarworks.umt.edu/tme/vol14/ iss $1 / 8$.

Kadivar, P., Tanha, Z., Sh, J., \& Farzad, V. 
(1993). Effect of epistemological beliefs, learning approach and Reflective thinking on academic achievement. Recent Researches in Sociology, Financing, Environment, and Health Science, 151156.

Kramarski, B., Mevarech, Z., \& Arami, M. (2002). The effects of metacognitive instruction on solving mathematical authentic tasks. Educational Studies in Mathematics, 49(2), 225-250. doi:10.1023/A:1016282811724.

Kurniawati, L., Kusumah, Y. S., Sumarmo, U., \& Sabandar, J. (2014). Enhancing students' mathematical intuitive-reflective thinking ability through problem-based learning with hypnoteaching method. Journal of Education and Practice, 5(36), 130-136. https://www.iiste.org/Journals/index.php/ JEP/article/view/17480.

Margolinas (Ed.). (2013). Proceedings of ICMI study 22: Task design in mathematics education. Oxford, UK: International Commission on Mathematical Instruction (ICMI).

Ministry of Education \& Culture. (2013). Pergeseran paradigma belajar Abad 21. https://lpmpriau.kemdikbud.go.id/ pergeseran-paradigma-belajar-abad-21/.

McDonald, S., \& Watson, A. (2010). What's in a task? Generating mathematically rich activity. Oxford, UK: QCDA.

Moulds, P. (2002). Rich tasks: Developing student learning around important tasks. Australian Science Teachers Journal, 48(4), 6-13.

Narmaditya, B. S., Wulandari, D., \& Sakarji, S. R. (2018). Does problem-based learning improve critical thinking skills? Cakrawala Pendidikan, 37(3), 378-388. doi:10.21831/cp.v38i3.21548.

Nuriadin, I., Kusumah, Y. S., Sabandar, J., \& Dahlan, J. A. (2015). Enhancing of students' mathematical reflective thinking ability through knowledge sharing learning strategy in senior high.
International Journal of Education and Research, 3(9), 255-268. http://www. ijern.com/September-2015.php.

Phan,H.P.(2006).Examinationofstudentlearning approaches, reflective thinking, and epistemological beliefs: A latent variables approach. Electronic Journal of Research in Educational Psychology, 4(10), 577610. doi:10.1080/01443410701349809.

Piggot, J. (2011). Rich task and contexts. http:// nrich.maths.org/5662.

Porntawekul, S., \& Raksasataya, S. (2012, 17-18 September). The development of reflective thinking instructional model for student teachers. Paper presented at $2^{\text {nd }}$ Annual International Conference on Education \& E-Learning (EeL), Bali, Indonesia. doi:10.5176/2251-1814 EeL12.118.

Queensland Department of Education. (2001). New basics project: Productive pedagogies. Brisbane: Author. http:// education.qld.gov.au.

Retnowati, E., Fathoni, Y., \& Chen, O. (2018). Mathematics problem solving skills acquisition: learning by problem posing or by problem solving. Cakrawala Pendidikan, 37(1), 1-10. doi:10.21831/cp/ v37i1.28787.

Santos, J. R. A. (1999). Cronbach's alpha: A tool for assessing the reliability of scales. Journal of Extension, 37(2), 1-5. https://www.joe.org/joe/1999april/ tt $3 . p h p \#: \sim:$ te $x \mathrm{t}=\mathrm{Sum}$ mated $\% 20$ scales $\% 20$ are $\% 20$ often $\% 20$ used,the $\% 20$ researcher $\% 20$ wants $\% 20$ to $\% 20$ measure. $\&$ text $=$ Cronbach's $\% 20$ alpha\%20determines\%20the $\% 20$ internal,instrument $\% 20$ to $\% 20$ gauge $\% 20$ its $\% 20$ reliability.

Saputra, M. D., Joyoatmojo, S., Wardani, D. K., \& Sangka, K. B. (2019). Developing criticalthinking skills through the collaboration of jigsaw model with problem-based learning model. International Journal of Instruction, 12(1), 1077-1094. doi:10.29333/iji.2019.12169a. 
Slavit, D., \& Nelson, T. H. (2010). Collaborative teacher inquiry as a tool for building theory on the development and use of rich mathematical tasks. Journal of Mathematics Teacher Education, 13(3), 201-221. doi:10.1007/s10857-0099136-x.

Stacey, K. (2011). The PISA view of mathematics literacy in Indonesia. Journal on Mathematics Education, 2(1), 1-24. doi:10.22342/jme.2.2.746.95-126.

Tanujaya, B., Prahmana, R. C. I., \& Mumu, J. (2017). Mathematics instruction, problems, challenges and opportunities: A case study in Manokwari Regency, Indonesia. World Transactions on Engineering and Technology Education, 15(3), 287-291. http://eprints.uad. ac.id/8062/.
Tessmer, M. (1993). Planning and conducting formative evaluations: Improving the quality of education and training. London: Kogan Page.

van der Schaaf, M., Baartman, L., Prins, F., Oosterbaan, A., \& Schaap, H. (2013). Feedback dialogues that stimulate students' reflective thinking. Scandinavian Journal of Educational Research, 57(3), 227-245. doi:10.1080/00313831.2011.62 8693.

Weshah, H. (1997). Measuring the effect of problem-based learning instructional program on reflective thinking development. Journal of Instructional Psychology, 39(3/4), 262-271.

Yin, R. K. (2003). Case study research: Design and methods ( $\left.3^{\text {rd }} \mathrm{ed}\right)$. London: Sage. 